\title{
L-glutamine ameliorates adipose-hepatic dysmetabolism in OC-treated female rats
}

\author{
Kehinde Samuel Olaniyi ${ }^{1,2}$ and Lawrence Aderemi Olatunji ${ }^{1}$ \\ ${ }^{1}$ HOPE Cardiometabolic Research Team \& Department of Physiology, College of Health Sciences, University of Ilorin, Ilorin, Nigeria \\ 2Department of Physiology, College of Medicine and Health Sciences, Afe Babalola University, Ado-Ekiti, Nigeria
}

Correspondence should be addressed to K S Olaniyi: kennethnitty2010@gmail.com

\begin{abstract}
Adipose dysfunction and inflammation with or without hepatic defects underlie metabolic obesity. Glutamine (GLU) improves glucoregulation and metabolic indices but its effects on adipose function and hepatic lipid deposition in estrogen-progestin oral contraceptive (EPOC) users are unknown. Therefore, we hypothesized that GLUT supplementation would protect against adipose dysfunction and excess hepatic lipid influx and deposition in EPOC-treated animals by suppressing adenosine deaminase/ xanthine oxidase (ADA/XO) activity and improving glucose-6-phosphate dehydrogenase (G6PD)-dependent antioxidant defense. Female Wistar rats weighing 150-180 g were allotted into control, GLUT, EPOC and EPOC + GLUT groups (six rats/group). The groups received vehicle (distilled water, p.o.), GLUT (1 g/kg), EPOC containing $1.0 \mu \mathrm{g}$ ethinylestradiol plus $5.0 \mu \mathrm{g}$ levonorgestrel and EPOC plus GLUT, respectively, daily for 8 weeks. Results showed that the administration of EPOC caused glucose dysregulation and increased triglyceride-glucose index and visceral adiposity, but the body weight and liver weight were not affected. However, EPOC significantly decreased adipose lipid, G6PD and glutathione and increased glycogen synthesis, ADA, XO, uric acid, lipid peroxidation, lactate production and gamma-glutamyl transferase activity (GGT). On the other hand, EPOC increased hepatic lipid, ADA, XO, uric acid, lipid peroxidation and lactate production and decreased glycogen synthesis, G6PD and glutathione. Nevertheless, supplementation with glutamine attenuated these alterations. Collectively, the present results indicate that EPOC causes metabolically induced obesity which is associated with adipose dysfunction and hepatic metabolic disturbance. The findings also suggest that glutamine confers metabo-protection with corresponding improvement in adipose and hepatic metabolic function by suppression of ADA/XO activity and enhancement of G6PD-dependent antioxidant defense.
\end{abstract}
Key Words
- adipose function
- antioxidant defense
- estrogen-progestin
- hepatic function
- metabolic obesity

Journal of Endocrinology (2020) 246, 1-12

\section{Introduction}

Overweight, obesity and type 2 diabetes mellitus are closely related health problems of global significance that are leading causes of cardiometabolic disease, particularly in women (Guzder et al. 2006, Rosamond et al. 2007). According to World Health Organization (WHO) report,
$39 \%$ of the world's adults ( $40 \%$ women) were found to be overweight, while about $13 \%$ (15\% women) were obese (https://www.who.int/news-room/fact-sheets/detail/ obesity-and-overweight). Although excess weight gain has been strongly associated with deleterious effects that 
increase the risk of premature death, as well as chronic metabolic disorders, there is an emerging hypothesis that body weight or BMI alone may not fully reveal the metabolic risk of an individual (Visscher et al. 2001). This obesity 'paradox' was initially observed by Ruderman and co-workers in Metabolically Obese Normal Weight (MONW) women that displayed metabolic phenotypes including impaired insulin signaling, dyslipidemia and systemic inflammation, all of which are central to the development of metabolic syndrome (Ruderman et al. 1981, Conus et al. 2004, Carnethon et al. 2012). The MONW syndrome has been an understudied concept, despite its increasing prevalence over time, coupled with the lack of criteria for and difficulty of early diagnosis due to the normal body weight/BMI and young age of subjects. However, some studies including a recent study from our laboratory animals have shown that MONW individuals could be identified based on increased lipid profiles or the triglyceride-glucose (TyG) index which is a proven marker of insulin resistance (Lee et al. 2015, Olaniyi et al. 2019).

Excessive accumulation of fat in the abdominal region is a strong predictor of insulin resistance (IR); however, other factors such as genetic or environmental factors can predispose individuals to the development of this condition, since there are obese patients without insulin resistance as well as lean individuals who are resistant to insulin action (Lebovitz \& Banerji 2005). In IR condition, adipose tissue function is impaired, which causes efflux of excess lipids into circulation from where deposition occurs in non-adipose tissues, particularly the liver (Crescenzo et al. 2015, Einer et al. 2018, Sergi et al. 2019). This hepatic lipid deposition has been documented as a strong predictor of non-alcoholic fatty liver disease (NAFLD), which can progress to liver disease (Wei et al. 2008, Feng et al. 2014). The severity of fatty liver disease has been previously associated with visceral fat accumulation and IR in both obese and non-obese subjects, suggesting that hepatic fatty infiltration in NAFLD may be influenced by visceral fat accumulation irrespective of body weight/BMI (Eguchi et al. 2006), although the mechanism remains unclear.

Combined oral contraceptive (COC), including estrogenprogestin oral contraceptive (EPOC), is the most popular effective means of birth control with over 100 million users worldwide (Moschos \& Nitoda 2017, Rike et al. 2019). Its usage has been alternatively beneficial in the treatment of reproductive disorders such as dysmenorrhea and hormone replacement therapy for postmenopausal women. Despite the extensive clinical experience, many vascular and metabolic effects of COC steroids are under investigation. Changes in body weight are known to occur in some women, although the association remains subclinical except in individuals with concomitant risk such as hypertension, cigarette smoking, atherosclerosis and diabetes among others (Africander et al. 2011). Available data show varying responses in body weight and visceral fat with ensuing IR and metabolic disturbances (Morin et al. 2008, Moschos \& Nitoda 2017). In some experimental studies, COC treatments were reported to increase body weight and visceral adiposity, while other studies reported decreased or unchanged body weight despite evident increase in visceral adipose tissue mass and traditional markers of dysmetabolism (Gallo et al. 2004). This suggests that COC-induced IR is associated with increased visceral adiposity regardless of body weight gain. Understanding the pathophysiology that underlies MONW syndrome in COC users will not only provide valuable translation of the molecular and physiological significance of visceral adiposity, but will also inform clinical assessments of risk in MONW individuals with novel therapeutic measures that would protect women taking COCs including EPOC from the associated metabolic consequence.

Glutamine is a non-essential amino acid that is now known to be 'conditionally essential' in certain disease conditions. A number of studies in humans and animals have reported that glutamine confers beneficial effects on metabolic pathologies by improving insulin signaling, glucose homeostasis and regulation of gut microbiota. (Pratt et al. 2010, Cruzat et al. 2014, 2018, Jegatheesan et al. 2016, Olaniyi \& Olatunji 2019). Despite the existing findings on dietary or pharmacological approaches to improve metabolic profile in women with metabolic syndrome, there is no specific nutritional/pharmacological recommendation for protection against metabolic disorder in the MONW sub-population. Therefore, our hypothesis that L-glutamine (GLUT) supplementation would be a potential therapeutic remedy against adipose dysfunction and excess hepatic lipid deposition that possibly accompany MONW in animals treated with EPOC by suppressing adenosine deaminase (ADA) activity and improving glucose-6-phosphate dehydrogenase (G6PD)-dependent antioxidant defense is worth studying.

\section{Materials and methods}

\section{Animals}

The investigation was conducted by following the National Institutes of Health Guide for the Care and Use of Laboratory Animals and was approved by the Institutional Review Board of the University of Ilorin, and every effort was made to minimize both the number of animals used 
and their suffering. Adult female Wistar rats weighing between 150-180 $\mathrm{g}$ were obtained from the animal house of the College of Health Sciences, University of Ilorin (Ilorin, Nigeria). Rats had unlimited access to standard rat chow and tap water. After 1 week of acclimatization, the animals were randomly assigned to four groups ( $n=6 /$ group). Rats were maintained in the animal house under environmental conditions of temperature $\left(22-26^{\circ} \mathrm{C}\right)$, relative humidity (50-60\%) and $12 \mathrm{~h}$ light:12 $\mathrm{h}$ darkness cycle.

\section{Treatment}

Control group received vehicle (distilled water; p.o.), GLUT group received L-glutamine $(1 \mathrm{~g} / \mathrm{kg} ;$ LOBA Chemie), EPOC group received COC containing $1.0 \mu \mathrm{g}$ ethinylestradiol and $5.0 \mu \mathrm{g}$ levonorgestrel (Wyeth-Ayerst) and EPOC+ GLUT group received a combination of EPOC plus L-glutamine. The animals were treated daily for 8 weeks. Initial and final body weights were monitored, and the percentage of body weight gain was estimated.

\section{Sample preparation}

At the end of the treatment, the rats were anesthetized with sodium pentobarbital $(50 \mathrm{mg} / \mathrm{kg}$; i.p.). Blood was collected by cardiac puncture into heparinized tube and was centrifuged at $704 \boldsymbol{g}$ for $5 \mathrm{~min}$ at room temperature. Plasma was stored frozen until needed for biochemical assay.

\section{Liver weight (hepatic mass)}

The liver was excised, cleared of adhering connective tissues, blotted and weighed immediately and corrected to body weight to eliminate variability.

\section{Assessment of visceral adiposity}

After dissection, visceral fat mass was assessed as previously described (Schiavone et al. 2017, Olaniyi \& Olatunji 2019) by isolating and weighing the total perirenal, retroperitoneal and abdominal fat pad and corrected to body weight to eliminate variability.

\section{Preparation of hepatic, adipose and pancreatic tissue homogenates}

After dissection, each of the tissues was excised, cleared of adhering connective tissues and blotted. Thereafter, 100 $\mathrm{mg}$ of each tissue was carefully removed and homogenized with a glass homogenizer in cold phosphate buffer solution, centrifuged at $7826 \mathrm{~g}$ for $10 \mathrm{~min}$ at $4^{\circ} \mathrm{C}$.

\section{Glycemic and metabolic indices}

Terminal fasting blood glucose (FBG) was determined after the rats had a 12-h overnight fast on the day of killing. Blood glucose levels were determined with a glucometer (ONETOUCH®-Life Scan). Insulin resistance was determined using the homeostasis model assessment for IR $\quad($ HOMA-IR $=$ FBG $\quad(\mathrm{mmol} / \mathrm{L}) \times$ fasting insulin $(\mu \mathrm{U} / \mathrm{L}) / 22.5)$ (Hsing et al. 2003), while quantitative insulin sensitivity check index was used to determine insulin sensitivity; QUICKI $=1 /(\log$ (fasting insulin) $+\log$ (fasting glucose)) (Katz et al. 2000). Metabolically induced obesity was assessed using the triglyceride-glucose index, which is expressed as TyG $=\mathrm{Ln}(\mathrm{TG}(\mathrm{mg} / \mathrm{dL}) \times \mathrm{FPG}(\mathrm{mg} / \mathrm{dL}) / 2)$ (Lee et al. 2015, Olaniyi et al. 2019).

\section{Biochemical assays}

\section{Plasma and pancreatic insulin}

Plasma and pancreatic insulin concentration were determined using ELISA kits obtained from Ray Biotech. This method was based on the direct sandwich technique in which two monoclonal antibodies are directed against separate antigenic determinants on the insulin molecule.

\section{Lipid profile}

Triglycerides (TG), total cholesterol (TC) and free fatty acid (FFA) were estimated in the adipose and hepatic tissue homogenates by standardized colorimetric methods using assay kits obtained from Randox. The quantification of the tissue concentration of TG, TC and FFA (non-esterified) were determined by coupled enzyme assays which result in colorimetric $(570 \mathrm{~nm})$ products proportional to the TG, TC and FFA present, respectively (Miller et al. 2016, Paul $\&$ Borah 2017).

\section{Glycogen concentration and glycogen synthase activity}

Adipose and hepatic glycogen concentration and glycogen synthase activity were determined as previously described (Vilkova 1982, Vardanis 1992, Bezborodkina et al. 2014) using standard non-enzymatic and enzymatic spectrophotometric methods, respectively, and reagents obtained from Oxford Biomedical Research.

\section{Lipid peroxidation biomarker and \\ antioxidant-dependent parameters}

Malondialdehyde (MDA) is a marker of lipid peroxidation and was determined from adipose and 
hepatic tissue homogenates by standard non-enzymatic spectrophotometric method using assay kits from Oxford Biomedical Research. This method involves the reaction of MDAin thesamplewith thiobarbituricacid (TBA) togenerate a MDA-TBA adduct (Uchiyama \& Mihars 1978), which was quantified spectrophotometrically, whereas glucose-6phosphate dehydrogenase (G6PD) activity and glutathione (GSH) were determined using standard enzymatic and non-enzymatic spectrophotometric methods, respectively, with assay kits obtained from Oxford Biomedical Research. The G6PD activity spectrophotometric determination is based on the evaluation of absorbance at $340 \mathrm{~nm}$ given by NADPH formation; the quantitative evaluation is made by adding a precise amount of enzyme solution to an assay mixture containing the substrate (glucose-6-phosphate) and its cofactor NADP; the rate of NADPH generation is spectrophotometrically measured at wavelength of 340 $\mathrm{nm}$ (Beutler 1984). Whereas, GSH spectrophotometric determination was based on the oxidation of GSH in the sample by the sulfhydryl reagent 5,5'-dithio-bis (2-nitrobenzoic acid) (DTNB) to form the yellow derivative 5'-thio-2-nitrobenzoic acid (TNB), measured at $412 \mathrm{~nm}$. The glutathione disulfide (GSSG) formed was recycled to GSH by glutathione reductase in the presence of NADPH (Rahman et al. 2006).

\section{Lactate concentration and lactate dehydrogenase activity}

Lactate concentration and lactate dehydrogenase (LDH) activity were determined in the adipose and hepatic tissue homogenates using standardized non-enzymatic and enzymatic colorimetric methods, respectively, and assay kit obtained from Randox. The colorimetric determination of lactate was based on the oxidation of lactate by lactate oxidase into pyruvate and hydrogen peroxide. The hydrogen peroxide is then detected with colorimetric probe. The reaction between the probe and hydrogen peroxide was catalyzed by horseradish peroxidase (Robergs et al. 2004) and quantified at $570 \mathrm{~nm}$. Detection of LDH activity was based on the oxidation of NAD to NADH by LDH, which was specifically detected by colorimetric (450 nm) assay (Lu et al. 2008).

\section{Gamma-glutamyl transferase}

Gamma-glutamyl transferase (GGT) activities were determined from adipose and hepatic tissue homogenates as previously described (Phillip \& Graham 1995, Young 2001) using standard spectrophotometric method and reagents obtained from Randox.

\section{Adenosine deaminase activity, xanthine oxidase activity and uric acid concentration}

From adipose and hepatic tissue homogenates, adenosine deaminase (ADA) and xanthine oxidase (XO) activities in addition to uric acid concentration were estimated by standard enzymatic and non-enzymatic colorimetric methods, respectively, using assay kits from Randox and in compliance with the manufacturers' assay procedures.

\section{Data analysis and statistics}

All data were expressed as means \pm S.E.M. Statistical group analysis was performed with SPSS. One-way ANOVA was used to compare the mean values of variables among the groups. Bonferroni's test was used to identify the significance of pairwise comparisons of mean values among the groups. $P$ values less than 0.05 were accepted as statistically significant.

\section{Results}

Effects of L-glutamine on body weight, visceral adiposity and liver weight in estrogen-progestin oral contraceptive-treated female rats

Administration of EPOC significantly increased visceral adiposity $(16.43 \pm 1.22$ vs $9.62 \pm 0.84 \mathrm{~g} / \mathrm{kg} ; P<0.05)$ when compared with control group, this has been earlier documented to be central to the development of metabolic obesity (Stanhope et al. 2009, Adeyanju et al. 2018). However, EPOC did not significantly alter the body weight $(26.28 \pm 3.00$ vs $28.95 \pm 2.30 \%)$ and liver weight/hepatic mass $(11.50 \pm 1.29$ vs $9.78 \pm 0.84 \mathrm{~g} / \mathrm{kg})$ when compared with control group. Besides, supplementation with glutamine decreased visceral adiposity $(10.64 \pm 1.40$ vs $16.43 \pm 1.22 \mathrm{~g} / \mathrm{kg}$; $P<0.05$ ) when compared with EPOC-treated group (Fig. 1).

\section{Effects of L-glutamine on glycemic and metabolic indices in estrogen-progestin oral contraceptive-treated female rats}

The administration of EPOC increased HOMA-IR $(8.90 \pm 1.12$ vs $4.07 \pm 0.34 ; P<0.05)$, which is an indicator of insulin resistance (Hsing et al. 2003). Similarly, EPOC increased plasma $(49.61 \pm 2.70$ vs $23.31 \pm 0.72 \mu \mathrm{IU} / \mathrm{mL}$; $P<0.05)$ and pancreatic $(4.33 \pm 0.22$ vs $3.19 \pm 0.11 \mu \mathrm{IU} / 100$ mg tissue; $P<0.05)$ insulin concentration, but decreased insulin sensitivity $(0.43 \pm 0.013$ vs $0.51 \pm 0.010 ; P<0.05)$, as revealed by QUICKI (Katz et al. 2000), with no significant 

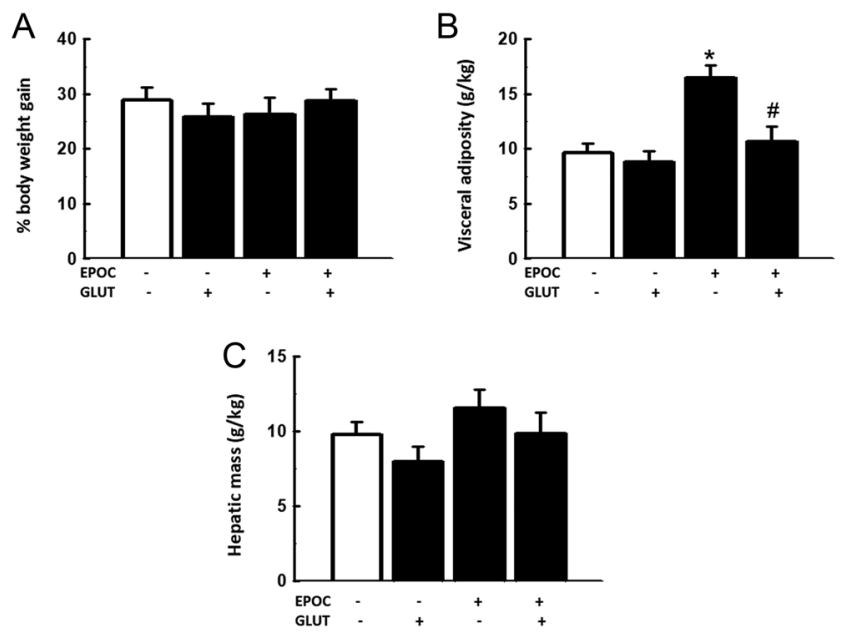

Figure 1

Effects of L-glutamine (GLUT) on body weight (A), visceral adiposity (B) and liver weight (C) in estrogen-progestin oral contraceptive (EPOC)-treated female rats. EPOC increases visceral adiposity but not body weight and liver weight. However, glutamine supplementation attenuates the alterations. Data are expressed as mean \pm S.E.M. $n=6$. Data were analysed by one-way ANOVA followed by Bonferroni post hoc test ( ${ }^{*} P<0.05$ vs control; $\# P<0.05$ vs EPOC).

change in glycemic level $(4.15 \pm 0.16$ vs $3.82 \pm 0.23)$ when compared with control group. It also increased the triglyceride-glucose index $(11.14 \pm 0.35$ vs $9.17 \pm 0.30$; $P<0.05)$ which is a validated indicator of metabolically induced obesity (Lee et al. 2015, Olaniyi et al. 2019). However, supplementation with glutamine improved metabolically induced obesity $(9.80 \pm 0.32$ vs $11.14 \pm 0.35$; $P<0.05)$, insulin sensitivity $(0.49 \pm 0.015$ vs $0.43 \pm 0.013$; $P<0.05)$ and glucose homeostasis with corresponding decrease in plasma $(30.13 \pm 2.70$ vs $49.61 \pm 2.70 \mu \mathrm{IU} / \mathrm{mL}$; $P<0.05)$ and pancreatic $(3.25 \pm 0.18$ vs $4.33 \pm 0.22 \mu \mathrm{IU} / 100$ mg tissue; $P<0.05$ ) insulin concentration when compared with EPOC-treated group (Fig. 2).

\section{Effects of L-glutamine on adipose and hepatic lipid profile in estrogen-progestin oral contraceptive- treated female rats}

Estrogen-progestin oral contraceptive decreased adipose TG $(0.58 \pm 0.01$ vs $0.71 \pm 0.01 \mathrm{mg} / 100 \mathrm{mg}$ tissue; $P<0.05)$, TC $(0.93 \pm 0.05$ vs $1.16 \pm 0.03 \mathrm{mg} / 100 \mathrm{mg}$ tissue $3 ; P<0.05)$ and FFA $(2.41 \pm 0.07$ vs $2.80 \pm 0.05 \mathrm{mg} / 100 \mathrm{mg}$ tissue; $P<0.05)$, which implies increased lipolysis, whereas increased hepatic TG $(0.70 \pm 0.03$ vs $0.45 \pm 0.02 \mathrm{mg} / 100 \mathrm{mg}$ tissue; $P<0.05)$ and TC $(1.70 \pm 0.05$ vs $1.38 \pm 0.02 \mathrm{mg} / 100 \mathrm{mg}$ tissue; $P<0.05)$ but not FFA $(5.00 \pm 0.33$ vs $4.60 \pm 0.02 \mathrm{mg} / 100 \mathrm{mg}$ tissue) when compared with control group, and these result in hepatic lipid accumulation that possibly precedes fatty liver in obesity or metabolic disorders (Kitade et al. 2017). Nevertheless, glutamine supplementation significantly increased the lipid contents of adipose tissue (TG: $0.68 \pm 0.01$ vs $0.58 \pm 0.01 \mathrm{mg} / 100 \mathrm{mg}$ tissue, TC: $1.15 \pm 0.08$ vs $0.93 \pm 0.05 \mathrm{mg} / 100 \mathrm{mg}$ tissue and FFF: $2.76 \pm 0.07$ vs $2.41 \pm 0.06 \mathrm{mg} / 100 \mathrm{mg}$ tissue; $P<0.05)$ and decreased hepatic lipid (TG: $0.50 \pm 0.04$ vs $0.70 \pm 0.03 \mathrm{mg} / 100 \mathrm{mg}$ tissue and TC: $1.43 \pm 0.04$ vs $1.70 \pm 0.05 \mathrm{mg} / 100 \mathrm{mg}$ tissue; $P<0.05$ ) compared to the EPOC-treated group (Fig. 3).

\section{Effects of L-glutamine on adipose and hepatic glycogen concentration and glycogen synthase activity in estrogen-progestin oral contraceptive- treated female rats}

Estrogen-progestin oral contraceptive increased adipose glycogen synthesis with corresponding increase in glycogen synthase activity $(0.14 \pm 0.007$ vs $0.11 \pm 0.006$ $\mu / g$ protein; $P<0.05)$ and glycogen content $(0.51 \pm 0.03$ vs $0.38 \pm 0.01 \mu \mathrm{g} / 100 \mathrm{mg}$ tissue; $P<0.05$ ), causing adipose glycogen accumulation but decreased glycogen synthase
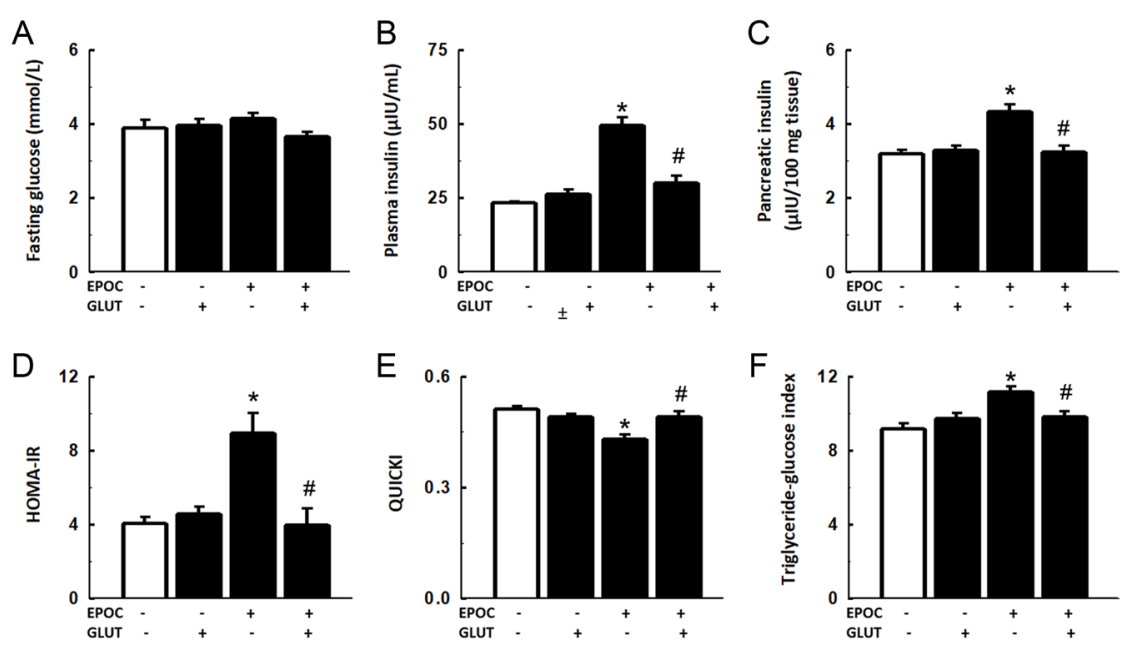

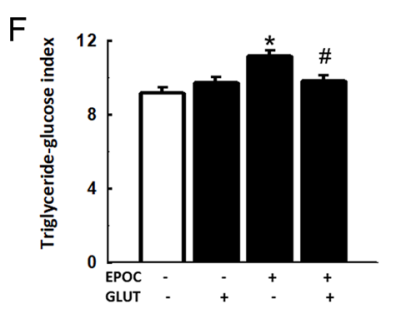

\section{Figure 2}

Effects of L-glutamine (GLUT) on glycemic and metabolic indices (A, B, C, D, E and F) in estrogenprogestin oral contraceptive (EPOC)-treated female rats. EPOC causes insulin resistance (HOMA-IR) and increases plasma and pancreatic insulin, but decreases insulin sensitivity (QUICKI). It also increases triglyceride-glucose index.

However, glutamine supplementation attenuates the alterations. Data are expressed as mean \pm S.E.M. $n=6$. Data were analysed by one-way ANOVA followed by Bonferroni post hoc test ( ${ }^{*} P<0.05$ vs control; $\# P<0.05$ vs EPOC). 
activity $(0.17 \pm 0.01$ vs $0.25 \pm 0.01 \mu / g$ protein; $P<0.05)$ and glycogen concentration $(0.96 \pm 0.04$ vs $1.34 \pm 0.05 \mu \mathrm{g} / 100$ mg tissue; $P<0.05)$ in the hepatic tissue compared with control group. In addition, EPOC-treated group decreased adipose glycogen synthase activity $(0.09 \pm 0.005$ vs $0.11 \pm 0.006 \mu / \mathrm{g}$ protein; $P<0.05)$ without significant effect on glycogen content $(0.36 \pm 0.02$ vs $0.38 \pm 0.01 \mu \mathrm{g} / 100 \mathrm{mg}$ tissue) when compared with the control group. However, supplementation with glutamine ameliorated adipose glycogen accumulation (glycogen content: $0.40 \pm 0.02$ vs $0.51 \pm 0.03 \mu \mathrm{g} / 100 \mathrm{mg}$ tissue and glycogen synthase activity: $0.12 \pm 0.006$ vs $0.14 \pm 0.007 \mu / g$ protein; $P<0.05$ ) and hepatic glycogen depletion (glycogen content: $1.24 \pm 0.08$ vs $0.96 \pm 0.04 \mu \mathrm{g} / 100 \mathrm{mg}$ tissue and glycogen synthase: $0.22 \pm 0.02$ vs $0.17 \pm 0.01 \mu / g$ protein; $P<0.05$ ) compared to the unsupplemented EPOC group (Fig. 4).

\section{Effects of L-glutamine on adipose and hepatic uric acid concentration, adenosine deaminase and xanthine oxidase activity in estrogen-progestin oral contraceptive-treated female rats}

Administration of EPOC increased adipose and hepatic ADA (adipose tissue: $0.048 \pm 0.0013$ vs $0.033 \pm 0.0015 \mu / \mathrm{g}$ protein and hepatic tissue: $0.22 \pm 0.012$ vs $0.14 \pm 0.011$ $\mu / g$ protein; $P<0.05)$ with correspondent increase in XO activity (adipose tissue: $0.12 \pm 0.006$ vs $0.08 \pm 0.004 \mu / \mathrm{g}$ protein and hepatic tissue: $0.60 \pm 0.02$ vs $0.42 \pm 0.02 \mu / g$ protein; $P<0.05$ ) and uric acid concentration (adipose tissue: $0.036 \pm 0.0015$ vs $0.020 \pm 0.0012 \mu / 100 \mathrm{mg}$ tissue and hepatic tissue: $0.067 \pm 0.0020$ vs $0.039 \pm 0.0014 \mu / 100 \mathrm{mg}$ tissue; $P<0.05)$ compared to the control group. Nonetheless, glutamine supplementation significantly reduced ADA (adipose tissue: $0.038 \pm 0.0020$ vs $0.048 \pm 0.0013 \mu / \mathrm{g}$ protein and hepatic tissue: $0.16 \pm 0.010$ vs $0.22 \pm 0.012 \mu / g$ protein; $P<0.05$ ), XO (adipose tissue: $0.09 \pm 0.008$ vs $0.12 \pm 0.006$ $\mu / g$ protein and hepatic tissue: $0.49 \pm 0.03$ vs $0.60 \pm 0.02$ $\mu / g$ protein; $P<0.05$ ) and uric acid concentration (adipose tissue: $0.027 \pm 0.0020$ vs $0.036 \pm 0.0015 \mu / 100 \mathrm{mg}$ tissue and hepatic tissue: $0.053 \pm 0.003$ vs $0.067 \pm 0.0020 \mu / 100$ $\mathrm{mg} ; \quad P<0.05)$ in both tissues when compared with the EPOC-treated group. Besides, the hepatic but not adipose XO activity (hepatic tissue: $0.49 \pm 0.03$ vs $0.42 \pm 0.02 \mu / 100$ mg; $P<0.05$ ) and uric concentration (hepatic tissue: $0.053 \pm 0.003$ vs $0.039 \pm 0.0014 \mu / 100 \mathrm{mg} ; P<0.05$ ) were significantly higher in EPOC+GLUT-treated compared to the control group (Fig. 5).

Effects of L-glutamine on adipose and hepatic lactate production and gamma-glutamyl transferase in estrogen-progestin oral contraceptive-treated female rats

Estrogen-progestin oral contraceptive increased lactate production which correlated with elevated LDH (adipose tissue: $0.51 \pm 0.030$ vs $0.32 \pm 0.020 \mu / g$ protein and hepatic tissue: $0.28 \pm 0.010$ vs $0.20 \pm 0.016 \mu / g$ protein; $P<0.05$ ) and lactate concentration (adipose tissue: $0.050 \pm 0.0015$ vs $0.040 \pm 0.0020 \mathrm{mg} / 100 \mathrm{mg}$ tissue and hepatic tissue: $0.17 \pm 0.008$ vs $0.11 \pm 0.002 \mathrm{mg} / 100 \mathrm{mg}$ tissue; $P<0.05$ ) in both tissues when compared with the control group. Notwithstanding, concomitant supplementation with glutamine significantly reduced LDH activity (adipose tissue: $0.40 \pm 0.020 \mathrm{vs} 0.51 \pm 0.030 \mu / \mathrm{g}$ protein and hepatic tissue: $0.22 \pm 0.015$ vs $0.28 \pm 0.010 \mu / g$ protein; $P<0.05$ ) and lactate concentration (adipose tissue: $0.038 \pm 0.0020$ vs $0.050 \pm 0.0015 \mathrm{mg} / 100 \mathrm{mg}$ tissue and hepatic tissue: $0.13 \pm 0.004$ vs $0.17 \pm 0.008 \mathrm{mg} / 100 \mathrm{mg}$ tissue; $P<0.05$ ) in
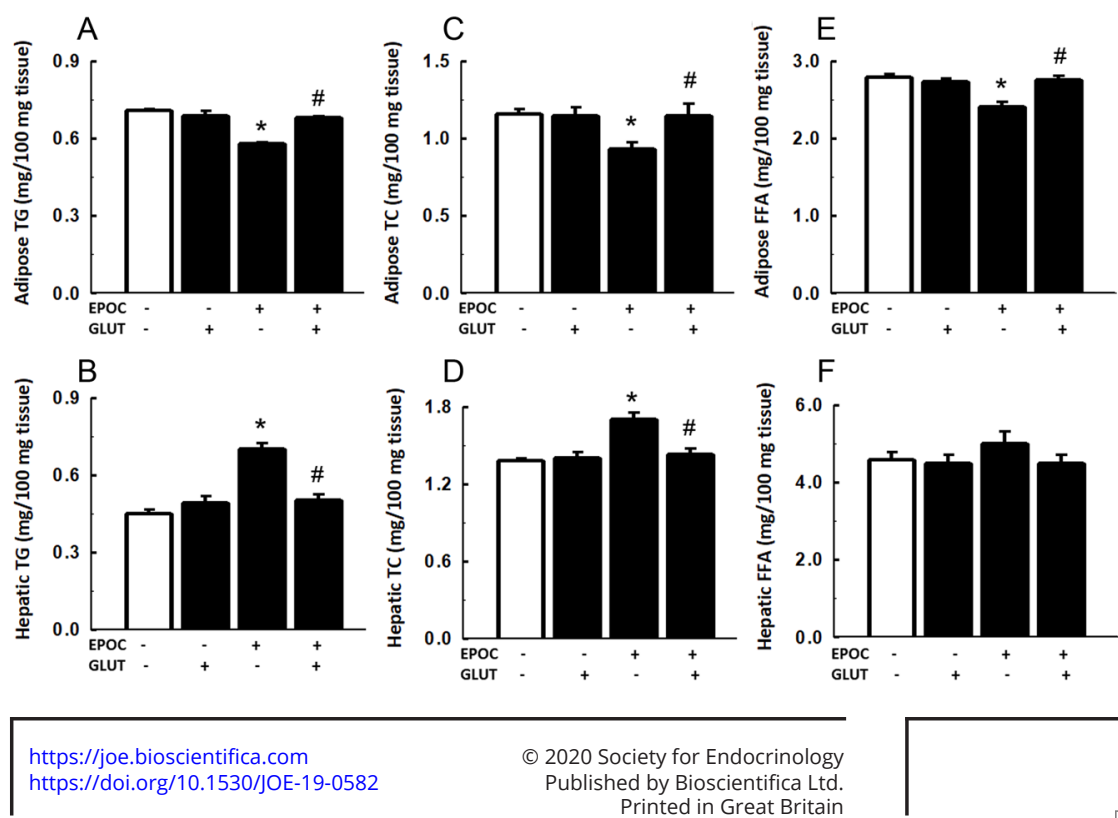

https://joe.bioscientifica.com https://doi.org/10.1530/JOE-19-0582
(C) 2020 Society for Endocrinology Printed in Great Britain Published by Bioscientifica Ltd.
Figure 3

Effects of L-glutamine (GLUT) on adipose and liver lipid profile (A, B, C, D, E and F) in estrogenprogestin oral contraceptive (EPOC)-treated female rats. EPOC decreases adipose triglyceride (TG), total cholesterol (TC) and free fatty acid (FFA), whereas liver TG and TC but not FFA significantly increase. Nevertheless,

supplementation with glutamine normalizes the changes. Data are expressed as mean \pm S.E.M. $n=6$. Data were analysed by one-way ANOVA followed by Bonferroni post hoc test ( ${ }^{*} P<0.05$ vs control; $\# P<0.05$ vs EPOC). 

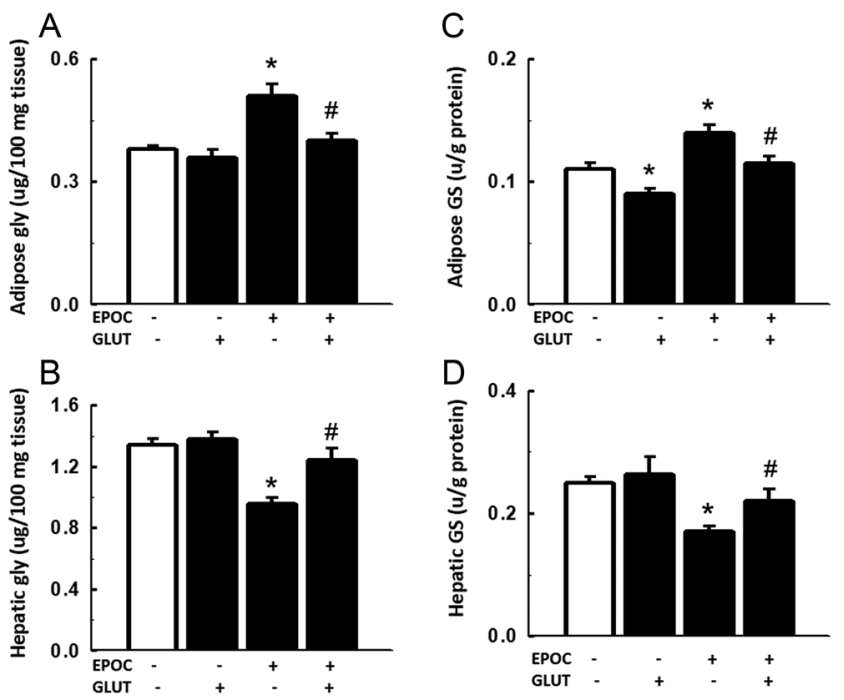

Figure 4

Effects of L-glutamine (GLUT) on adipose and liver glycogen (gly) and glycogen synthase (GS) activity (A, B, C and D) in estrogen-progestin oral contraceptive (EPOC)-treated female rats. EPOC increases adipose glycogen and glycogen synthase activity, whereas liver glycogen and glycogen synthase activity significantly decrease, and these alterations are reversed following glutamine supplementation. Data are expressed as mean \pm S.E.M. $n=6$. Data were analysed by one-way ANOVA followed by Bonferroni post hoc test ( ${ }^{*} P<0.05$ vs control; $\# P<0.05$ vs EPOC).

both tissues. Additionally, adipose but not hepatic LDH (adipose tissue: $0.40 \pm 0.020$ vs $0.32 \pm 0.020 \mu / \mathrm{g}$ protein; $P<0.05)$ was significantly higher in EPOC+GLUTtreated compared with control group. Similarly, EPOC increased adipose GGT $(0.34 \pm 0.017$ vs $0.27 \pm 0.022 \mu / \mathrm{g}$ protein; $P<0.05)$ but did not significantly affect hepatic GGT $(0.12 \pm 0.015$ vs $0.10 \pm 0.010 \mu / g$ protein $)$ when compared to the control group. Nevertheless, the GGT activity decreased significantly in the adipose tissue when supplemented with glutamine $(0.26 \pm 0.020$ vs $0.34 \pm 0.017 \mu / g$ protein; $P<0.05)$ compared with EPOCtreated group (Fig. 6).
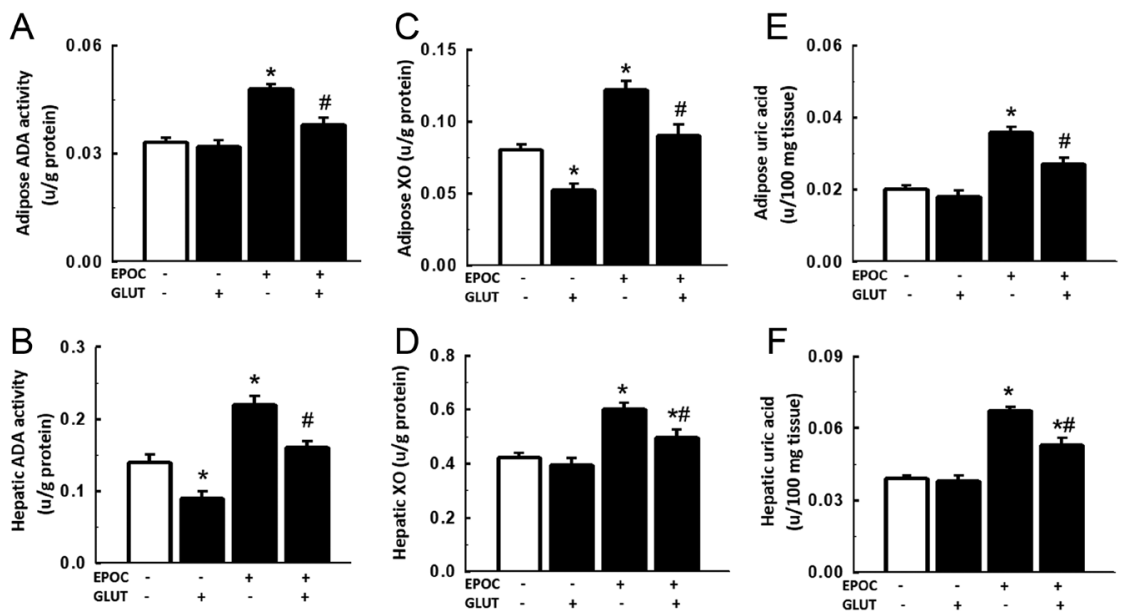

Effects of L-glutamine on adipose and hepatic malondialdehyde (lipid peroxidation) and glucose-6phosphate- and glutathione-dependent antioxidant defense in estrogen-progestin oral contraceptivetreated female rats

Administration of EPOC increased MDA (adipose tissue: $0.130 \pm 0.009$ vs $0.080 \pm 0.008 \mu \mathrm{M} / 100 \mathrm{mg}$ tissue and hepatic tissue: $0.18 \pm 0.008$ vs $0.11 \pm 0.002 \mu \mathrm{M} / 100 \mathrm{mg}$ tissue; $P<0.05$ ) and decreased G6PD activity (adipose tissue: $0.012 \pm 0.0009$ vs $0.015 \pm 0.0010 \mu / g$ protein and hepatic tissue: $0.019 \pm 0.001$ vs $0.024 \pm 0.0008 \mu / g$ protein; $P<0.05$ ) and GSH content (adipose tissue: $0.21 \pm 0.009$ vs $0.27 \pm 0.005 \mu / 100 \mathrm{mg}$ tissue and hepatic tissue: $0.45 \pm 0.02$ vs $0.53 \pm 0.01 \mu / 100 \mathrm{mg}$ tissue; $P<0.05$ ) in both tissues compared to the control group. These alterations (MDA, G6PD and GSH) were respectively attenuated by glutamine supplementation in both tissues ((adipose tissue: $0.090 \pm 0.010$ vs $0.130 \pm 0.009 \mu \mathrm{M} / 100 \mathrm{mg}$ tissue and hepatic tissue: $0.14 \pm 0.007$ vs $0.18 \pm 0.008 \mu \mathrm{M} / 100$ $\mathrm{mg}$ tissue; $P<0.05$ ), (adipose tissue: $0.0165 \pm 0.0008$ vs $0.0120 \pm 0.0009 \mu / g$ protein and hepatic tissue: $0.023 \pm 0.001$ vs $0.019 \pm 0.001 \mu / g$ protein; $P<0.05)$ and (adipose tissue: $0.26 \pm 0.006$ vs $0.21 \pm 0.009 \mu / 100 \mathrm{mg}$ tissue and hepatic tissue: $0.52 \pm 0.02$ vs $0.45 \pm 0.02 \mu / 100 \mathrm{mg}$ tissue; $P<0.05)$ ). However, hepatic but not adipose MDA concentration $(0.14 \pm 0.007$ vs $0.11 \pm 0.002 \mu \mathrm{M} / 100 \mathrm{mg}$ tissue; $P<0.05$ ) was significantly higher in EPOC+GLUTtreated compared to the control group (Fig. 7).

\section{Discussion}

The key finding from the present study is that glutamine supplementation protects against adipose dysfunction and hepatic metabolic disturbance with corresponding

\section{Figure 5}

Effects of L-glutamine (GLUT) on adipose and liver adenosine deaminase (ADA) activity, xanthine oxidase $(X O)$ activity and uric acid concentration $(A, B, C, D, E$ and $F)$ in estrogen-progestin oral contraceptive (EPOC)-treated female rats. EPOC increases adipose and liver ADA, XO and uric acid, and these alterations are attenuated by glutamine supplementation. Data are expressed as mean \pm S.E.M. $n=6$. Data were analysed by one-way ANOVA followed by Bonferroni post hoc test ( $* P<0.05$ vs control; $\# P<0.05$ vs EPOC). 
A

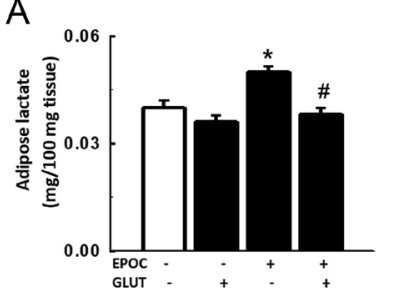

B

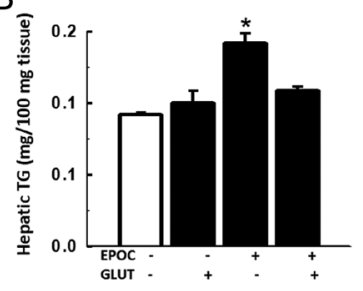

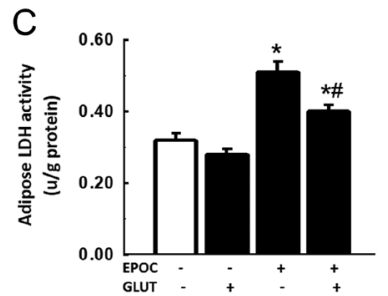

D

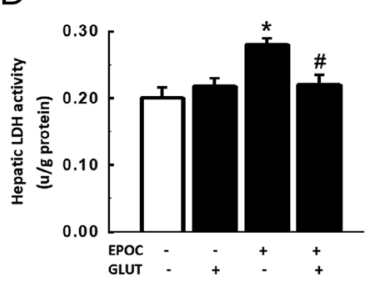

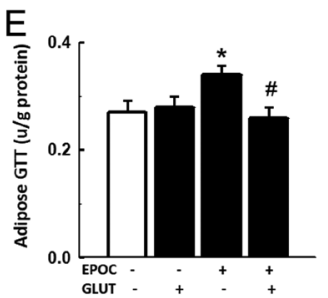

$\mathrm{F}$

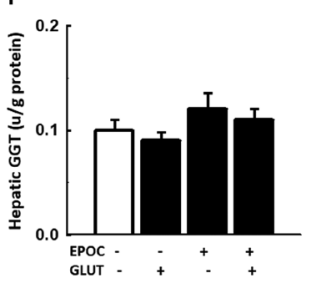

\section{Figure 6}

Effects of L-glutamine (GLUT) on adipose and liver lactate ( $A$ and $B$ ), lactate dehydrogenase ( $L D H ; C$ and $D$ ) and gamma-glutamyl transferase (GGT; $E$ and $F$ ) in estrogen-progestin oral contraceptive (EPOC)-treated female rats. EPOC increases adipose and liver lactate, LDH activity and adipose but not liver GGT activity. However, these alterations are attenuated by glutamine supplementation. Data are expressed as mean \pm S.E.M. $n=6$. Data were analysed by one-way ANOVA followed by Bonferroni post hoc test ( $* P<0.05$ vs control; $\# P<0.05$ vs EPOC). improvement in metabolically induced obesity in EPOCtreated rats, by suppression of $\mathrm{ADA} / \mathrm{XO}$ activity and enhancement of G6PD-dependent antioxidant defense. The results showed that EPOC causes metabolically induced obesity (MONW) with corresponding increase in visceral adiposity without significantly affecting the hepatic mass when compared with control group. Similarly, it disrupted glucose homeostasis by decreasing insulin sensitivity, a condition that resulted in hyperinsulinemia. Besides, EPOC decreased adipose lipid with an increase in glycogen synthesis but increased hepatic lipid with a decrease in glycogen synthesis. These changes were associated with increased adipose and hepatic ADAdependent pro-inflammation, lipid peroxidation, lactate production, defective G6PD- and glutathione-dependent antioxidant defense and increased adipose but not hepatic GGT activity. However, supplementation with glutamine ameliorated these metabolic perturbations that accompany the administration of EPOC (Fig. 8).

The present results validated our recent and earlier findings that COC, especially estrogen-progestin formulation, causes metabolically induced obesity (Olaniyi et al. 2019) in addition to insulin resistance, which is associated with disrupted glucose homeostasis, reduced insulin sensitivity and hyperinsulinemia (Olatunji et al. 2017a, Adeyanju et al. 2018, Michael \& Olatunji 2018) respectively. Similarly, the present study provides evidence that EPOC-induced glucose dysregulation is not due to impaired pancreatic function nor insulin secretion but attributable to reduced insulin sensitivity which previous studies have largely associated with impaired insulin signaling (Pereira et al. 2017, Ferrannini et al. 2018). This perhaps triggers insulin resistance that precedes the development of metabolically induced obesity in animals treated with EPOC. In addition, the metabolically induced obesity observed in the present study is associated with increased fat mass in the visceral compartment, and this is an integral part of metabolic obesity as previously demonstrated (Stanhope et al. 2009, Adeyanju et al. 2018). However, supplementation with glutamine was found to improve insulin sensitivity, glucose homeostasis and normalize visceral adiposity, which is sufficient to
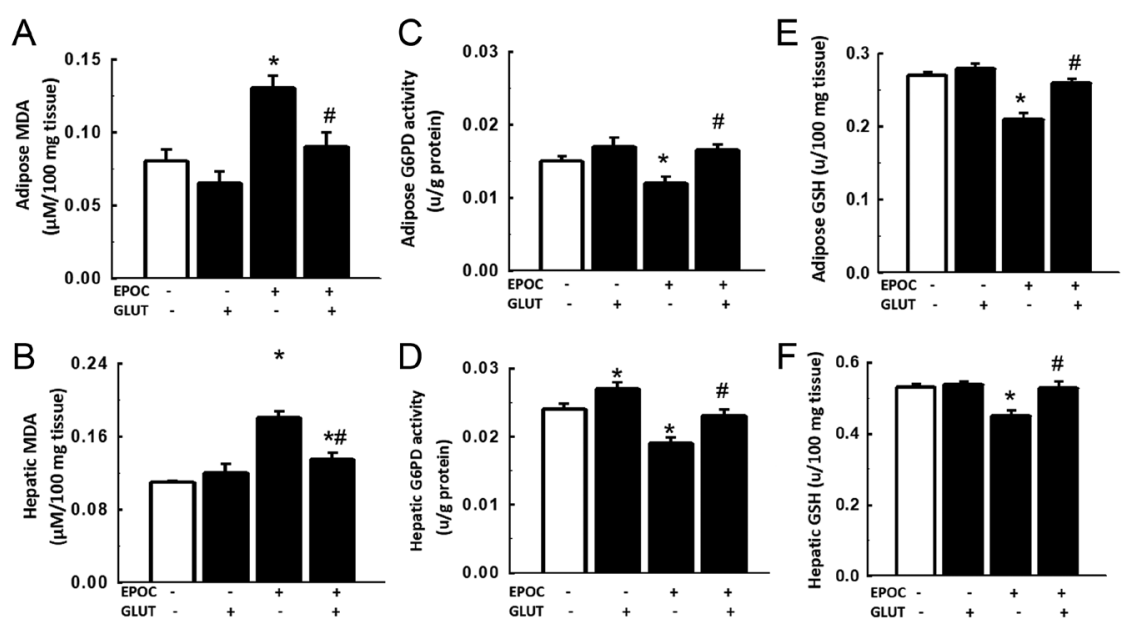

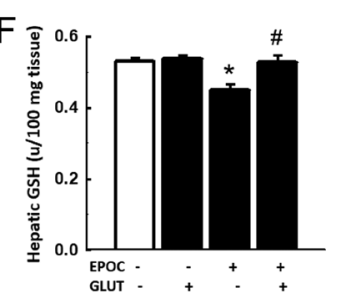

Figure 7

Effects of L-glutamine (GLUT) on adipose and liver malondialdehyde (MDA; A and B), glucose-6phosphate dehydrogenase (G6PD) activity ( $C$ and D) and glutathione (GSH; $E$ and F) in estrogenprogestin oral contraceptive (EPOC)-treated female rats. EPOC increases adipose and liver MDA and decreases G6PD activity and glutathione, which are ameliorated by glutamine supplementation. Data are expressed as mean \pm S.E.M. $n=6$. Data were analysed by one-way ANOVA followed by Bonferroni post hoc test ( ${ }^{*} P<0.05$ vs control; $\# P<0.05$ vs EPOC). https://joe.bioscientifica.com https://doi.org/10.1530/JOE-19-0582
(C) 2020 Society for Endocrinology Published by Bioscientifica Ltd.
Printed in Great Britain 


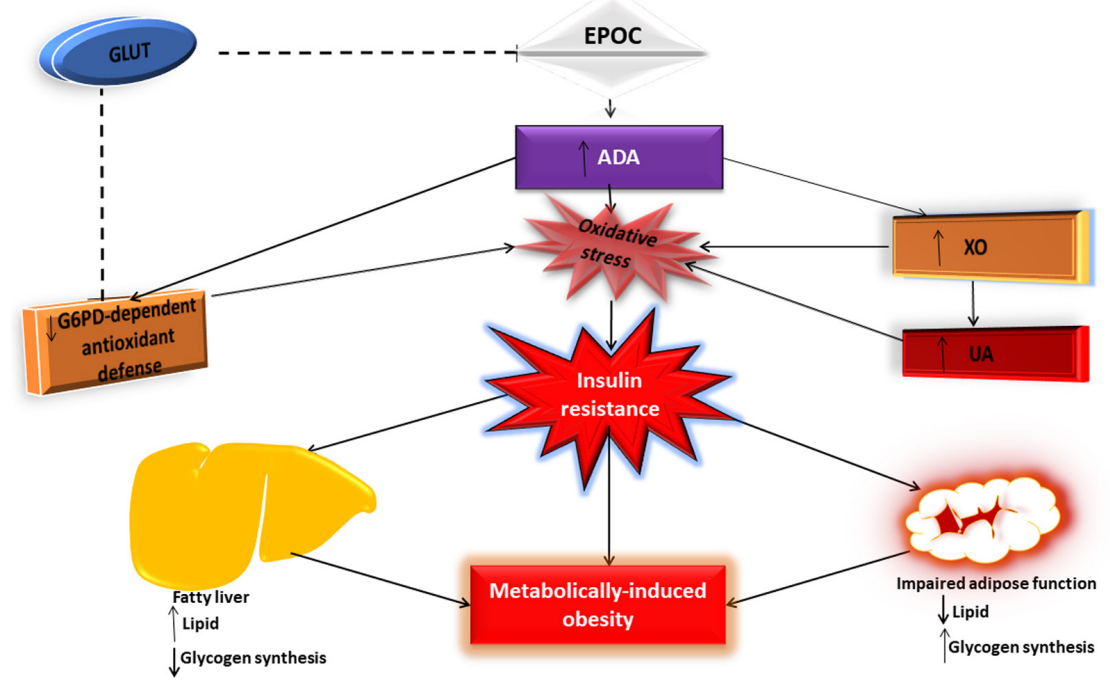

\section{Figure 8}

Pathway showing the induction of metabolically induced obesity by estrogen-progestin oral contraceptive (EPOC) and the interaction with glutamine (GLUT) in the amelioration of EPOC-induced metabolic effects. ADA, adenosine deaminase; $\mathrm{XO}$, xanthine oxidase; G6PD, glucose-6-phosphate dehydrogenase; UA, uric acid. A full color version of this figure is available at https://doi.org/10.1530/JOE-19-0582. restore metabolic health in EPOC+GLUT-treated animals. This observation is consistent with previous studies Cruzat et al. 2014, 2018, Jegatheesan et al. 2016) and the underlying mechanism worth probing.

It is not surprising that EPOC-induced insulin resistance increased lipolysis, leading to decreased adipose lipid profile including TG, TC and FFA and increasing lipid trafficking and ectopic deposition in non-adipose tissue especially the liver. Nonetheless, it is intriguing, despite this finding, to observe increased visceral adiposity which possibly contributes to metabolically induced obesity. Adipose tissue is responsible for fat storage including excess fat and its function as energy reservoir and endocrine tissue is a key factor in metabolic health. However, in insulin resistance-linked disorders, such as obesity, type 2 diabetes and other related metabolic syndromes, the white visceral adiposity increases, remodels and expands, leading to adipose dysfunction with consequent depletion of adipose triglyceride and other forms of lipids such as total cholesterol and free fatty acid. This may further aggravate systemic and hepatic insulin resistance (Haczeyni et al. 2015, Vishvanath \& Gupta 2019), possibly accompanying metabolically induced obesity and contributing to the cardiac events usually reported in EPOC users (Morin et al. 2008, Haarala et al. 2009, Sitruk-ware \& Nath 2013, Olatunji et al. 2017b). In addition, the increased adiposity is associated with elevated adipose glycogen content and glycogen synthase activity causing glycogen accumulation in the adipose tissue of the EPOC-treated animals. This is possibly due to redirection of glucose metabolic flux into glycogen synthesis in the adipose tissue, an observation that seems consistent with previous study by Ceperuelo-Mallafré et al., who demonstrated excessive glycogen deposition in the adipose tissue that triggers inflammatory-related metabolic stress and affects cellular secretory profile in insulin resistant-obese subject (Ceperuelo-Mallafré et al. 2016). Therefore, the present findings suggest that adipose dysfunction with corresponding increased adiposity and glycogen accumulation may at least, in part, contribute to the development of metabolically induced obesity in EPOC-treated animals.

On the other hand, the administration of EPOC led to increased hepatic triglyceride and total cholesterol, causing hepatic lipid deposition, which has been previously documented to contribute to hepatic lipotoxicity in individuals with insulin resistance-related syndromes (Samuel et al. 2010, Olaniyi \& Olatunji 2019). The excessive deposition of lipid without alteration in the level of the hepatic FFA possibly suggests that the EPOC-induced hepatic lipid accumulation is largely due to lipid influx into the liver, perhaps, resulting from insulin resistant adipose tissue. This effect may also be associated with impaired hepatic glycogen synthase activity that leads to decrease in hepatic glycogen content. An event similar to the previous reports that loss of hepatic glycogen synthesis diverts glucose toward fat synthesis, correlating with impaired hepatic insulin signaling and glucose disposal, and results in excess hepatic lipid that precedes hepatic steatosis (Obeid et al. 2000, Samuel et al. 2010, Williams et al. 2013) which is associated with metabolic obesity. However, glutamine, which is previously documented to improve insulin sensitivity (Jegatheesan et al. 2016, Cruzat et al. 2018), ameliorates EPOC-induced adipose dysfunction and hepatic lipid deposition. 
Importantly, the administration of EPOC significantly increased adipose and hepatic ADA activity with subsequent increase in $\mathrm{XO}$ and uric acid concentration, a proinflammatory-engendered process that is pathologically triggered possibly by decreased circulating estradiol following treatment with EPOC. An earlier study from our laboratory animals has associated an increase in circulating uric acid to decreased plasma estradiol and impaired glucose uptake after treatment with estrogen-progestin formulation of COC (Olatunji et al. 2017a). Besides, ADA is a rate-limiting enzyme that deaminates intracellular pool of adenosine and deoxyadenosine, leading to uric acid production through XO activity. It is known to elicit a pro-inflammatory response and promote oxidative stress via the activity of $\mathrm{XO}$, as reflected by elevated adipose and hepatic lipid peroxidation in this study, and at least in part contributes to adipose glycogen-induced pro-inflammatory metabolic signals and hepatic oxidative insults that accompany metabolically induced obesity in EPOC-treated animals. This is similar to previous studies including a recent study from our group which reported increased $\mathrm{ADA}$ and $\mathrm{XO}$ in metabolic-related disorders, particularly prediabetes, type 2 diabetes mellitus and cardiomyopathy among others (Feoli et al. 2014, Domingueti et al. 2016, Li et al. 2018, Olaniyi \& Olatunji 2019). In addition, EPOC administration decreased house-keeping enzyme-G6PDand GSH-dependent antioxidant defense when compared with control, which further reduced cellular resistance to oxidative stress, inducing cellular injuries as revealed by elevated lactate production and GGT in adipose tissue and lactate production but not GGT in hepatic tissue. Nevertheless, supplementation with glutamine decreased ADA-dependent pro-inflammation and lipid peroxidation with corresponding improvement of G6PD activity and GSH content in both tissues. This seems consistent with earlier studies that demonstrated beneficial effects of glutamine in metabolic pathologies including type 2 diabetes, cardiac hypertrophy and liver disease among others, and its beneficial effects have been linked to its antiinflammatory and antioxidant properties (Grau et al. 2011, Million et al. 2013, Olaniyi \& Olatunji 2019). Therefore, the present study suggests for the first time that glutamine supplementation improves adipose function and hepatic lipid deposition by suppression of ADA-dependent proinflammation and enhancement of G6PD-and GSHdependent antioxidant defense. Nevertheless, this study is not without mechanistic limitation, particularly the molecular mechanism underlying the modulatory effects of glutamine in EPOC-treated animals. Regardless, the study in addition provides justification for a detailed focus on the molecular mechanism underpinning the regulatory role of glutamine in EPOC users and the data generated could possibly impact safety in over 100 million women that use OC, particularly EPOC.

\section{Conclusion}

The present study demonstrates that metabolically induced obesity invoked by estrogen-progestin oral contraceptive is accompanied by adipose dysfunction and hepatic metabolic disturbance. The findings also suggest that glutamine confers metabo-protection with corresponding improvement in adipose and hepatic metabolic function by suppression of $\mathrm{ADA} / \mathrm{XO}$ activity and enhancement of G6PD-dependent antioxidant defense. Therefore, glutamine supplementation could be employed as intervention against metabolically induced obesity, adipose dysfunction and metabolic-related liver disorders. The molecular mechanism underlying the regulatory role of glutamine in EPOC-treated animals/ users should be explored in future studies.

\section{Declaration of interest}

The authors declare that there is no conflict of interest that could be perceived as prejudicing the impartiality of the research reported.

\section{Funding}

This research did not receive any specific grant from funding agencies in the public, commercial or not-for-profit sectors.

\section{Author contribution statement}

$\mathrm{K} \mathrm{S} \mathrm{O}$ and $\mathrm{L} \mathrm{A} \mathrm{O} \mathrm{conceived} \mathrm{and} \mathrm{designed} \mathrm{the} \mathrm{research.} \mathrm{K} \mathrm{S} \mathrm{O} \mathrm{conducted}$ the experiments. $\mathrm{KS} \mathrm{O}$ and $\mathrm{LAO}$ contributed to the new reagents and analytical kits, analyzed and interpreted the data, drafted the manuscript and read and approved the final manuscript.

\section{References}

Adeyanju OA, Soetan OA, Soladoye AO \& Olatunji LA 2018 Oral hormonal therapy with ethin[ylestradiol/levonorgestrel improves insulin resistance, obesity and glycogen synthase kinase-3 independent of circulating mineralocorticoid in estrogen-deficient rats. Canadian Journal of Physiology and Pharmacology 96 577-586. (https://doi.org/10.1139/cjpp-2017-0630)

Africander D, Verhoog N \& Hapgood JP 2011 Molecular mechanisms of steroid receptor-mediated actions by synthetic progestins used in HRT and contraception. Steroids 76 636-652. (https://doi.org/10.1016/j. steroids.2011.03.001)

Beutler E 1984 Red Cell Metabolism: A Manual of Biochemical Methods, 3rd ed. New York, NY, USA: Grune \& Strattan. (c) 2020 Society for Endocrinology Published by Bioscientifica Ltd. Printed in Great Britain 
Bezborodkina NN, Chestnova AY, Okovity SV \& Kudryavtseva BN 2014 Activity of glycogen synthase and glycogen phosphorylase in normal and cirrhotic rat liver during glycogen synthesis from glucose or fructose. Experimental and Toxicologic Pathology 66 147-154. (https:// doi.org/10.1016/j.etp.2013.12.001)

Carnethon MR, De Chavez PJ, Biggs ML, Lewis CE, Pankow JS, Bertoni AG, Golden SH, Liu K, Mukamal KJ, Campbell-Jenkins B, et al. 2012 Association of weight status with mortality in adults with incident diabetes. JAMA 308 581-590. (https://doi.org/10.1001/jama.2012.9282)

Ceperuelo-Mallafré V, Ejarque M, Serena C, Duran X, Montori-Grau M, Rodríguez MA, Yanes O, Núñez-Roa C, Roche K, Puthanveetil P, et al. 2016 Adipose tissue glycogen accumulation is associated with obesity-linked inflammation in humans. Molecular Metabolism 5 5-18. (https://doi.org/10.1016/j.molmet.2015.10.001)

Conus F, Allison DB, Rabasa-Lhoret R, St-Onge M, St-Pierre DH, Tremblay-Lebeau A \& Poehlman ET 2004 Metabolic and behavioral characteristics of metabolically obese but normal-weight women. Journal of Clinical Endocrinology and Metabolism 89 5013-5020. (https://doi.org/10.1210/jc.2004-0265)

Crescenzo R, Bianco F, Mazzoli A, Giacco A, Liverini G \& Iossa S 2015 Mitochondrial efficiency and insulin resistance. Frontiers in Physiology 5 512. (https://doi.org/10.3389/fphys.2014.00512)

Cruzat VF, Krause M \& Newsholme P 2014 Amino acid supplementation and impact on immune function in the context of exercise. Journal of the International Society of Sports Nutrition 11 61. (https://doi. org/10.1186/s12970-014-0061-8)

Cruzat V, Macedo Rogero M, Noel Keane K, Curi R \& Newsholme P 2018 Glutamine: metabolism and immune function, supplementation and clinical translation. Nutrients 10 1564. (https://doi.org/10.3390/ nu10111564)

Domingueti CP, Dusse LM, Carvalho Md, de Sousa LP, Gomes KB \& Fernandes AP 2016 Diabetes mellitus: the linkage between oxidative stress, inflammation, hypercoagulability and vascular complications. Journal of Diabetes and its Complications 30 738-745. (https://doi. org/10.1016/j.jdiacomp.2015.12.018)

Eguchi Y, Eguchi T, Mizuta T, Ide Y, Yasutake T, Iwakiri R, Hisatomi A, Ozaki I, Yamamoto K, Kitajima Y, et al. 2006 Visceral fat accumulation and insulin resistance are important factors in nonalcoholic fatty liver disease. Journal of Gastroenterology 41 462-469. (https://doi. org/10.1007/s00535-006-1790-5)

Einer C, Hohenester S, Wimmer R, Wottke L, Artmann R, Schulz S, Gosmann C, Simmons A, Leitzinger C, Eberhagen C, et al. 2018 Mitochondrial adaptation in steatotic mice. Mitochondrion 40 1-12. (https://doi.org/10.1016/j.mito.2017.08.015)

Feng RN, Du SS, Wang C, Li YC, Liu LY, Guo FC \& Sun CH 2014 Lean-non-alcoholic fatty liver disease increases risk for metabolic disorders in a normal weight Chinese population. World Journal of Gastroenterology 20 17932-17940. (https://doi.org/10.3748/wjg.v20. i47.17932)

Feoli AM, Macagnan FE, Piovesan CH, Bodanese LC \& Siqueira IR 2014 Xanthine oxidase activity is associated with risk factors for cardiovascular disease and inflammatory and oxidative status markers in metabolic syndrome: effects of a single exercise session. Oxidative Medicine and Cellular Longevity 2014 587083. (https://doi. org/10.1155/2014/587083)

Ferrannini E, Iozzo P, Virtanen KA, Honka MJ, Bucci M \& Nuutila P 2018 Adipose tissue and skeletal muscle insulin-mediated glucose uptake in insulin resistance: role of blood flow and diabetes. American Journal of Clinical Nutrition 108 749-758. (https://doi.org/10.1093/ajcn/nqy162)

Gallo MF, Grimes DA, Schulz KF \& Helmerhorst FM 2004 Combination estrogen-progestin contraceptives and body weight: systematic review of randomized controlled trials. Obstetrics and Gynecology 103 359-373. (https://doi.org/10.1097/01.AOG.0000107298.29343.6a)

Grau T, Bonet A, Miñambres E, Piñeiro L, Irles JA, Robles A, Acosta J, Herrero I, Palacios V, Lopez J, et al. 2011 The effect of L-alanyl-Lglutamine dipeptide supplemented total parenteral nutrition on infectious morbidity and insulin sensitivity in critically ill patients. Critical Care Medicine 39 1263-1268. (https://doi.org/10.1097/ CCM.0b013e31820eb774)

Guzder RN, Gatling W, Mullee MA \& Byrne CD 2006 Impact of metabolic syndrome criteria on cardiovascular disease risk in people with newly diagnosed type 2 diabetes. Diabetologia 49 49-55. (https://doi. org/10.1007/s00125-005-0063-9)

Haarala A, Eklund C, Pessi T, Lehtimäki T, Huupponen R, Jula A, Viikari J, Raitakari O \& Hurme M 2009 Use of combined oral contraceptives alters metabolic determinants and genetic regulation of C-reactive protein. The cardiovascular risk in Young Finns Study. Scandinavian Journal of Clinical and Laboratory Investigation 69 168-174. (https:// doi.org/10.1080/00365510802449642)

Haczeyni F, Barn V, Mridha AR, Yeh MM, Estevez E, Febbraio MA, Nolan CJ, Bell-Anderson KS, Teoh NC \& Farrell GC 2015 Exercise improves adipose function and inflammation and ameliorates fatty liver disease in obese diabetic mice. Obesity 23 1845-1855. (https:// doi.org/10.1002/oby.21170)

Hsing AW, Gao YT, Chua Jr S, Deng J \& Stanczyk FZ 2003 Insulin resistance and prostate cancer risk. Journal of the National Cancer Institute 95 67-71. (https://doi.org/10.1093/jnci/95.1.67)

Jegatheesan P, Beutheu S, Ventura G, Sarfati G, Nubret E, Kapel N, Waligora-Dupriet AJ, Bergheim I, Cynober L \& De-Bandt JP 2016 Effect of specific amino acids on hepatic lipid metabolism in fructoseinduced non-alcoholic fatty liver disease. Clinical Nutrition $\mathbf{3 5}$ 175-182. (https://doi.org/10.1016/j.clnu.2015.01.021)

Katz A, Nambi SS, Mather K, Baron AD, Follmann DA, Sullivan G \& Quon MJ 2000 Quantitative insulin sensitivity check index: a simple, accurate method for assessing insulin sensitivity in humans. Journal of Clinical Endocrinology and Metabolism 85 2402-2410. (https://doi. org/10.1210/jcem.85.7.6661)

Kitade H, Chen G, Ni Y \& Ota T 2017 Nonalcoholic fatty liver disease and insulin resistance: new insights and potential new treatments. Nutrients 9 387-100. (https://doi.org/10.3390/nu9040387)

Lebovitz HE \& Banerji MA 2005 Point: visceral adiposity is causally related to insulin resistance. Diabetes Care 28 2322-2325. (https://doi. org/10.2337/diacare.28.9.2322)

Lee SH, Han K, Yang HK, Kim HS, Cho JH, Kwon HS, Park YM, Cha BY \& Yoon KH 2015 A novel criterion for identifying metabolically obese but normal weight individuals using the product of triglycerides and glucose. Nutrition and Diabetes 5 e149. (https://doi.org/10.1038/ nutd.2014.46)

Li X, Meng X, Gao X, Pang X, Wang Y, Wu X, Deng X, Zhang Q, Sun C $\&$ Li Y 2018 Elevated serum xanthine oxidase activity is associated with the development of Type 2 diabetes: a prospective cohort study. Diabetes Care 41 884-890. (https://doi.org/10.2337/dc17-1434)

Lu F, Chauhan AK, Fernandes SM, Walsh MT, Wagner DD \& Davis III AE 2008 The effect of C1 inhibitor on intestinal ischemia and reperfusion injury. American Journal of Physiology: Gastrointestinal and Liver Physiology 295 G1042-G1049. (https://doi.org/10.1152/ ajpgi.90460.2008)

Michael OS \& Olatunji LA 2018 Ameliorative effect of nicotine exposure on insulin resistance is accompanied by decreased cardiac glycogen synthase kinase- 3 and plasminogen activator inhibitor-1 during oral oestrogen-progestin therapy. Archives of Physiology and Biochemistry 124 139-148. (https://doi.org/10.1080/13813455.2017.1369549)

Miller DB, Snow SJ, Henriquez A, Schladweiler MC, Ledbetter AD, Richards JE, Andrews DL \& Kodavanti UP 2016 Systemic metabolic derangement, pulmonary effects, and insulin insufficiency following subchronic ozone exposure in rats. Toxicology and Applied Pharmacology 306 47-57. (https://doi.org/10.1016/j.taap.2016.06.027)

Million M, Lagier JC, Yahav D \& Paul M 2013 Gut bacterial microbiota and obesity. Clinical Microbiology and Infection 19 305-313. (https:// doi.org/10.1111/1469-0691.12172)

Morin P, Martikainen L \& McCarthy MI 2008 Comparison of metabolic and inflammatory outcomes in women who used oral contraceptives https://joe.bioscientifica.com https://doi.org/10.1530/JOE-19-0582 (c) 2020 Society for Endocrinology Published by Bioscientifica Ltd. Printed in Great Britain 
and the levonorgestrel-releasing intrauterine device in a general population. American Journal of Obstetrics and Gynecology 199 1-10. (https://doi.org/10.1016/j.ajog.2008.04.013)

Moschos MM \& Nitoda E 2017 The impact of combined oral contraceptives on ocular tissues: a review of ocular effects. International Journal of Ophthalmology 10 1604-1610. (https://doi. org/10.18240/ijo.2017.10.19)

Obeid OA, Powell-Tuck J \& Emery PW 2000 The postprandial rates of glycogen and lipid synthesis of lean and obese female Zucker rats. International Journal of Obesity and Related Metabolic Disorders 24 508-513. (https://doi.org/10.1038/sj.ijo.0801189)

Olaniyi KS \& Olatunji LA 2019 Inhibition of pyruvate dehydrogenase kinase- 4 by l-glutamine protects pregnant rats against fructose-induced obesity and hepatic lipid accumulation. Biomedicine and Pharmacotherapy 110 59-67. (https://doi.org/10.1016/j.biopha.2018.11.038)

Olaniyi KS, Sabinari IW \& Olatunji LA 2019 L-glutamine supplementation exerts cardio-renal protection in estrogen-progestin oral contraceptivetreated female rats. Environmental Toxicology and Pharmacology $\mathbf{7 4}$ 103305. (https://doi.org/10.1016/j.etap.2019.103305)

Olatunji LA, Olaniyi KS, Usman TO, Abolarinwa BA, Achile CJ \& Kim IK $2017 a$ Combined oral contraceptive and nitric oxide synthesis inhibition synergistically causes cardiac hypertrophy and exacerbates insulin resistance in female rats. Environmental Toxicology and Pharmacology 52 54-61. (https://doi.org/10.1016/j.etap.2017.03.012)

Olatunji LA, Usman TO, Seok YM \& Kim IK 2017b Activation of cardiac renin-angiotensin system and plasminogen activator inhibitor-1 gene expressions in oral contraceptive-induced cardiometabolic disorder. Archives of Physiology and Biochemistry 123 1-8. (https://doi.org/10.31 09/13813455.2016.1160935)

Paul R \& Borah A 2017 Global loss of acetylcholinesterase activity with mitochondrial complexes inhibition and inflammation in brain of hypercholesterolemic mice. Scientific Reports 7 17922. (https://doi. org/10.1038/s41598-017-17911-z)

Pereira RM, Botezelli JD, da Cruz Rodrigues KC, Mekary RA, Cintra DE, Pauli JR, da Silva ASR, Ropelle ER \& de Moura LP 2017 Fructose consumption in the development of obesity and the effects of different protocols of physical exercise on the hepatic metabolism. Nutrients 9 405-426. (https://doi.org/10.3390/nu9040405)

Phillip MA \& Graham RP 1995 Designing a coupled assay system for aspartate aminotransferase. Biochemistry Education 23 40-41.

Pratt WB, Morishima Y, Peng HM \& Osawa Y 2010 Proposal for a role of the Hsp90/Hsp70-based chaperone machinery in making triage decisions when proteins undergo oxidative and toxic damage. Experimental Biology and Medicine 235 278-289. (https://doi. org/10.1258/ebm.2009.009250)

Rahman I, Kode A \& Biswas SK 2006 Assay for quantitative determination of glutathione and glutathione disulfide levels using enzymatic recycling method. Nature Protocols 1 3159-3165. (https://doi. org/10.1038/nprot.2006.378)

Rike P, Anett MM, Martin J, Julia W, Mathias W, Alfons OH \& Alexander L 2019 Oral contraceptives impair complex emotion recognition in healthy women. Frontiers in Neuroscience 12 101041. (https://doi. org/10.3389/fnins.2018.01041)

Robergs RA, Ghiasvand F \& Parker D 2004 Biochemistry of exerciseinduced metabolic acidosis. American Journal of Physiology: Regulatory, Integrative and Comparative Physiology 287 R502-R516. (https://doi. org/10.1152/ajpregu.00114.2004)
Rosamond W, Flegal K, Friday G, Furie K, Go A, Greenlund K, Haase N, Ho M, Howard V, Kissela B, et al. 2007 Heart disease and stroke statistics - 2007 update: a report from the American Heart Association Statistics Committee and Stroke Statistics Subcommittee. Circulation 115 e69-e171. (https://doi.org/10.1161/CIRCULATIONAHA.106.179918)

Ruderman NB, Schneider SH \& Berchtold P 1981 The 'metabolicallyobese,' normal-weight individual. American Journal of Clinical Nutrition 34 1617-1621. (https://doi.org/10.1093/ajcn/34.8.1617)

Samuel VT, Petersen KF \& Shulman GI 2010 Lipid-induced insulin resistance: unravelling the mechanism. Lancet 375 2267-2277. (https://doi.org/10.1016/S0140-6736(10)60408-4)

Schiavone S, Camerino GM, Mhillaj E, Zotti M, Colaianna M, De Giorgi A, Trotta A, Cantatore FP, Conte E, Bove M, et al. 2017 Visceral fat dysfunctions in the rat social isolation model of psychosis. Frontiers in Pharmacology 8 87. (https://doi.org/10.3389/ fphar.2017.00787)

Sergi D, Naumovski NN, Heilbronn LK, Abeywardena M, O'Callaghan N, Lionetti L \& Luscombe-Marsh NL 2019 Mitochondrial (Dys) function and insulin resistance: from pathophysiological molecular mechanisms to the impact of diet. Frontiers in Physiology 10532. (https://doi.org/10.3389/fphys.2019.00532)

Sitruk-Ware R \& Nath A 2013 Characteristics and metabolic effects of estrogen and progestins contained in oral contraceptive pills. Best Practice and Research: Clinical Endocrinology and Metabolism 27 13-24. (https://doi.org/10.1016/j.beem.2012.09.004)

Stanhope KL, Schwarz JM, Keim NL, Griffen SC, Bremer AA, Graham JL, Hatcher B, Cox CL, Dyachenko A, Zhang W, et al. 2009 Consuming fructose-sweetened, not glucose-sweetened, beverages increase visceral adiposity and lipids and decreases insulin sensitivity in overweight/ obese humans. Journal of Clinical Investigation 119 1322-1334. (https://doi.org/10.1172/JCI37385)

Uchiyama M \& Mihars M 1978 Determination of malondialdehyde precursor in tissues by thiobarbituric acid. Annals of Biochemistry $\mathbf{8 6}$ 271-278.

Vardanis A 1992 Particulate glycogen of mammalian liver: specificity in binding phosphorylase and glycogen synthase. Biochemistry and Cell Biology 70 523-527. (https://doi.org/10.1139/o92-081)

Vilkova VA 1982 Methods of Biochemical Research. Leningrad, Russia: LGU Press.

Vishvanath L \& Gupta RK 2019 Contribution of adipogenesis to healthy adipose tissue expansion in obesity. Journal of Clinical Investigation 129 4022-4031. (https://doi.org/10.1172/JCI129191)

Visscher TL, Seidell JC, Molarius A, van der Kuip D, Hofman A \& Witteman JC 2001 A comparison of body mass index, waist-hip ratio and waist circumference as predictors of all-cause mortality among the elderly: the Rotterdam study. International Journal of Obesity and Related Metabolic Disorders 25 1730-1735. (https://doi.org/10.1038/ sj.ijo.0801787)

Wei Y, Rector RS, Thyfault JP \& Ibdah JA 2008 Nonalcoholic fatty liver disease and mitochondrial dysfunction. World Journal of Gastroenterology 14 193-199. (https://doi.org/10.3748/wjg.14.193)

Williams DJ, Edwards D, Hamernig I, Jian L, James AP, Johnson SK \& Tapsell LC 2013 Vegetables containing phytochemicals with potential anti-obesity properties: a review. Food Research International 52 323-333. (https://doi.org/10.1016/j.foodres.2013.03.015)

Young DS 2001 Effects of Disease on Clinical Laboratory Tests, 4th ed. Washington, DC, USA: AACC Press.

Received in final form 16 April 2020

Accepted 20 April 2020

Accepted Manuscript published online 20 April 2020 https://joe.bioscientifica.com https://doi.org/10.1530/JOE-19-0582 (c) 2020 Society for Endocrinology Published by Bioscientifica Ltd. Printed in Great Britain 